\title{
Forthcoming Meetings and Conferences of General Interest
}

For inclusion in this list, information must reach the MLA four months before publication of the issue in which the listing should appear.

American Association for the Advancement of the Humanities, 22-24 Oct. 1982, Washington, DC. Address Gary Rubin, AAAH, Suite 601, 918 16th St., NW, Washington, DC 20006.

Hispanic Literature Conference, 22-23 Oct. 1982, Indiana Univ. of Pennsylvania. Address J. C. Mendizabal, Dept. of Foreign Langs. and Lits., 407 Sutton Hall, Indiana Univ. of Pennsylvania, Indiana, PA 15705.

Mid-America Linguistics Conference, 22-23 Oct. 1982, Univ. of Kansas. Address Linguistics Dept., Univ. of Kansas, Lawrence 66045.

Conference for Foreign Language Teachers, 23 Oct. 1982, Youngstown State Univ. Address Conference for Foreign Language Teachers, Dept. of Foreign Langs., Youngstown State Univ., Youngstown, $\mathrm{OH} 44555$.

Conference on Christianity and Literature (North East Region), 23 Oct. 1982, Concordia Coll. Address Thomas Sluberski, Dept. of English, Concordia Coll., Bronxville, NY 10708.

American Society for Aesthetics, 27-30 Oct. 1982, Banff. Address Hilde Hein, Dept. of Philosophy, Holy Cross Coll., Worcester, MA 01610.

Sixteenth-Century Studies Conference, 28-30 Oct. 1982, St. Louis. Address Robert Kolb, Concordia Coll., Hamline and Marshall Aves., St. Paul, MN 55104.

Research Society for Victorian Periodicals, 29-30 Oct. 1982, New York. Address Rosemary T. VanArsdel, Dept. of English, Univ. of Puget Sound, Tacoma, WA 98416, or Joel Wiener, Dept. of History, City Univ. of New York, Convent Ave. at 138th St., New York, NY 10031.

African Studies Association, 3-7 Nov. 1982, Washington, DC. Address African Studies Assn., 255 Kinsey Hall, Univ. of California, 405 Hilgard Ave., Los Angeles 90024.

International Society for Individualized Instruction, 3-5 Nov. 1982, Purdue Univ. Address ISII, PO Box 1090, Lawrence, KS 66044.

International Conference on Twentieth-Century Women Writers, 4-7 Nov. 1982, Hofstra Univ. Address Natalie Datlof and Alexej Ugrinsky, University Center for Cultural and Intercultural Studies, Hofstra Univ., Hempstead, NY 11550.

Midwest Modern Language Association, 4-6 Nov. 1982, Cincinnati. Address Thomas E. Lewis, 423 EPB, Univ. of Iowa, Iowa City 52242.
Society for Critical Exchange Symposium on the Work of Fredric Jameson, 4 Nov. 1982, Miami Univ. Address James J. Sosnoski, Dept. of English, Bachelor Hall, Miami Univ., Oxford, OH 45056.

Southeastern Conference on Linguistics, 4-5 Nov. 1982, Atlanta. Address Reza Ordoubadian, Box 275, Middle Tennessee State Univ., Murfreesboro 37132.

Speech Communication Association, 4-7 Nov. 1982, Louisville. Address William Work, Speech Communication Assn., 5105 Backlick Road, Annandale, VA 22003.

Conference on Editorial Problems: Editing PolymathsErasmus to Russell, 5-6 Nov. 1982, Univ. of Toronto. Address Sharon Butler, 14285 Robarts Library, Univ. of Toronto, Toronto, Ont., Canada M5S 1A5.

Conference on German-Americana in the Eastern United States, 5-7 Nov. 1982, Gettysburg Coll. Address Michael Ritterson, Dept. of German, Gettysburg Coll., Gettysburg, PA 17325, or Steven Benjamin, Dept. of Foreign Langs., Radford Univ., Radford, VA 24142.

Conference on South Asia, 5-7 Nov. 1982, Madison. Address Program Committee, South Asian Area Center, 1258 Van Hise Hall, Univ. of Wisconsin, Madison 53706.

Barnard Pedagogy Conference: Interdisciplinary Methodology in Medieval and Renaissance Studies, 6 Nov. 1982, Barnard Coll. Address Catherine McGee, 413 Lehman Hall, Barnard Coll., New York, NY 10027.

International Conference: Cinema Histories, Cinema Practices II, 9-12 Nov. 1982, Univ. of Wisconsin, Milwaukee. Address Patricia Mellencamp and Carol Tennessen, Center for Twentieth Century Studies, P.O. Box 413, Univ. of Wisconsin, Milwaukee 53201.

Colloquium on the Hispanic Romancero and Other Traditional Poetic Forms, 11-13 Nov. 1982, Mexico City. Address Mercedes Díaz Roig or Beatriz Mariscal de Rhett, El Colegio de México, CELL, Camino al Ajusco 20, Pedregal de Sta. Teresa, México 20, D.F. 10740.

Conference on Latin American Women Writers, 11-13 Nov. 1982, Mt. Holyoke and Smith Colls. Address Eliana Ortega, Dept. of Spanish and Italian, Mt. Holyoke Coll., S. Hadley, MA 01075, or Patricia González, Smith Coll., Northampton, MA 01063.

Frost: Modern Dimensions, 11-13 Nov. 1982, Central State Univ. Address R. F. Fleissner, Dept. of English, Central State Univ., Wilberforce, OH 45384. 
Society for Ethnomusicology, 11-14 Nov. 1982, College Park. Address Carol Robertson, Univ. of Maryland, College Park 20742.

South Atlantic Modern Language Association, 11-13 Nov. 1982, Atlanta. Address Donald Kay, SAMLA Office, Drawer CA, University, AL 35486.

Arkansas Philological Association, 12-13 Nov. 1982, Arkansas State Univ. Address George F. Horneker, Dept. of English, Arkansas State Univ., State University 72467.

George Sand International Conference, 12-13 Nov. 1982, Bard Coll. Address Isabelle Naginski, Div. of Langs. and Lits., Bard Coll., Annandale-on-Hudson, NY 12504.

Philological Association of the Pacific Coast, 12-14 Nov. 1982, Univ. of Oregon. Address Frances Smith Foster, English Dept., San Diego State Univ., San Diego, CA 92182.

Symposium on Spanish and Portuguese Bilingualism, 12-13 Nov. 1982, Mayagüez, PR. Address Bilingual Symposium Director, Dept. of Spanish and Portuguese, Univ. of Massachusetts, Amherst 01003.

Cushwa Center for the Study of American Catholicism: Perspectives on American Catholicism, 19-20 Nov. 1982, Univ. of Notre Dame. Address Cushwa Center, 614 Memorial Library, Notre Dame, IN 46556.

Intellectual Skills Development, 19-20 Nov. 1982, Western Michigan Univ. Address Office of Conferences and Insts., Div. of Continuing Education, Western Michigan Univ., Kalamazoo 49008.

Medieval Workshop on the Mozarabs, 19-20 Nov. 1982, Univ. of British Columbia. Address H. E. Kassis, Dept. of Religious Studies, Univ. of British Columbia, Vancouver, BC, Canada V6T $1 \mathrm{~W} 5$.

National Council of Teachers of English, 19-24 Nov. 1982, Washington, DC. Address NCTE, 1111 Kenyon Road, Urbana, IL 61801.

The Writer Makes History: Writers and Works That Have Changed the World, 19 Nov. 1982, Nassau Comm. Coll. Address Joan Sevick, Dept. of English, Nassau Comm. Coll., Garden City, NY 11530.

American Association of Teachers of French (jointly with AATG and ACTFL), 23-27 Nov, 1982, New York. Address Fred M. Jenkins, Univ. of Illinois, 57 E. Armory Ave., Champaign 61820.

American Association of Teachers of German, 25-28 Nov. 1982, New York. Address Robert A. Govier, AATG, Suite 201, 523 Bldg., Route 38, Cherry Hill, NJ 08034

American Council on the Teaching of Foreign Languages, 25-27 Nov. 1982, New York. Address ACTFL, 385 Warburton Ave., Hastings-on-Hudson, NY 10706.
Mid-Hudson Modern Language Association, 29-30 Nov. 1982, Marist Coll. Address George J. Sommer, English Dept., Marist Coll., Poughkeepsie, NY 12601.

Association for Jewish Studies, 19-21 Dec. 1982, Boston. Address Steven T. Katz, Center for Jewish Studies, Harvard Univ., 6 Divinity Ave., Cambridge, MA 02138 .

American Institute for Writing Research, 27-30 Dec. 1982, Los Angeles. Address Serban C. Andronescu, Grand Central Station, Box 1364, New York, NY 10163 .

Modern Language Association, 27-30 Dec. 1982, Los Angeles. Address Convention Manager, MLA, 62 Fifth Ave., New York, NY 10011.

American Historical Association, 28-30 Dec. 1982, Washington, DC. Address Samuel Gammon, 400 A St., SE, Washington, DC 20003.

Linguistic Society of America, 28-30 Dec. 1982, San Diego. Address Victoria A. Fromkin, LSA, 3520 Prospect St., NW, Washington, DC 20007.

Conference on Microcomputers and Literary Scholarship: Editions, Concordances, and Stylistic Analyses, 30 Dec. 1982, Clark Library. Address George Guffey, William Andrews Clark Library, 2520 Cimarron St., Los Angeles, CA 90018.

Europe and Asia 600-1600, Institutions and Ideas, 2-5 Jan. 1983, Univ. of Hawaii. Address Cornelia N. Moore, Committee on Medieval Studies, Moore Hall 483, Univ. of Hawaii, Honolulu 96822.

University of California Dickens Project: Dickens and the Fantastic, 2-4 Jan. 1983, Univ. of California, Riverside. Address Murray Baumgarten, Dickens Project, Kresge Coll., Univ. of California, Santa Cruz 95064

Mississippi Philological Association, 21-22 Jan. 1983, Jackson State Univ. Address Wilton Beauchamp, Dept. of English, Jackson State Univ., Jackson, MS 39217.

Comparative Literature Symposium: Feminine Dimensions of Science Fiction and Fantasy, 26-28 Jan. 1983, Texas Tech Univ. Address Jane B. Weedman, Dept. of English, Texas Tech Univ., Lubbock 79409.

Florida State University Comparative Literature Circle Conference on Literature and Film, 27-29 Jan. 1983, Tallahassee. Address JoAnn James, Dept. of Modern Langs, and Ling., Florida State Univ., Tallahassee 32306.

Southern Humanities Conference: Humanities-The Contemporary Scene, 3-5 Feb. 1983, Salem Coll. and North Carolina School of the Arts. Address William L. Tribby, Dept. of General Studies, PO Box 12189 , North Carolina School of the Arts, Winston-Salem 27107.

Société des Professeurs Français en Amérique, 5 Feb. 1983, Douglass Coll. Address Société des Professeurs 


\section{Fitzgerald, postmodernism, American autobiography, Holocaust theatre, the Age of Johnson, and a growing world of criticism... all from WISCONSIN}

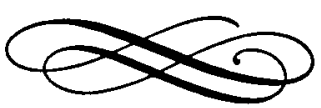

\section{THE SHORT STORIES OF E. SCOTT FITZGERALD} NEW APPROACHES IN CRITICISM Jackson R. Bryer, editor. Fitzgerald's short stories have long remained the most seriously neglected aspect of his total work. In an effort to redress this critical imbalance, Jackson R. Bryer has gathered together a group of insightful essays which together explicate the novelist's stories, suggesting their rich and unmined critical potential. November 1982. 384 pages. $\$ 30.00 / 7.95$.

\section{THE DISMEMBERMENT OF ORPHEUS}

\section{TOWARD A POSTMODERN LITERATURE}

SECOND EDITION - EXPANDED

Ihab Hassan. The author takes Orphic dismemberment and regeneration as his metaphor for a radical crisis in art and language, culture and consciousness, which prefigures postmodern literature. For this new edition. Hassan has added a new preface and postface on the developing character of postmodernism, a concept which he himself has done much to theorize. August 1982. 336 pages. $\$ 25.00 / 8.95$.

\section{A BIBLIOGRAPHY OF AMERICAN AUTOBIOGRAPHY}

1945-1980

Mary Louise Briscoe, editor. This annotated bibliography comes as a particularly welcome reference to scholars, researchers, and librarians. Providing current data on an exhaustive range of recent American autobiographies, Briscoe's work supplements and updates Louis Kaplan's long-popular listing of pre-1945 titles, and includes vastly expanded coverage of titles on women, Blacks, and numerous ethnic groups. October 1982. Price to be announced.

\begin{abstract}
THE THEATRE OF THE HOLOCAUST FOUR PLAYS

Robert Skloot, editor. In this seminal work, Skloot sets out to identify, analyze, and present samples of the Theatre of the Holocaust, a genre whose compelling and forceful contribution to Holocaust and theatre studies has too long been neglected. The resulting volume is both a powerful testimony and a critical anthology, the first of its kind for scholars, students, and the general reader concerned with Holocaust studies.

October 1982. 416 pages, illus. \$25.00/10.95.
\end{abstract}

\section{JOHN HAWKESWORTH, EIGHTEENTH- CENTURY MAN OF LETTERS}

John Lawrence Abbott. This complete biography of Hawkesworth introduces original evidence to define the life of a man who helped to shape the cultural life of Great Britain in the later eighteenth century. Without a knowledge of Hawkesworth's life, our understanding of the literary and cultural life of the Age of Johnson remains incomplete.

September 1982. 320 pages. Cloth $\$ 22.50$.

\section{THE UNKNOWN SAMUEL JOHNSON}

John J. Burke, Jr. and Donald Kay, editors. The eminently quotable Johnson of Boswell's Life and popular legend has overshadowed Johnson the writer and thinker. The essays collected here corroborate that argument, revealing an engaging, provocative, and largely unknown Johnson, the literary figure we once thought we knew so well. Essential new reading for all Johnsonians. November 1982. 224 pages. Cloth $\$ 30.00$

\section{$\rightarrow \infty$ \\ THE UNIVERSITY OF WISCONSIN PRESS}

114 North Murray Street, Madison, Wisconsin 53715 One Gower Street, London WC1E 6HA 
Français en Amérique, 22 E. 60th St., New York, NY 10022.

Louisiana Conference on Hispanic Languages and Literatures, 10-12 Feb. 1983, Tulane Univ. Address Gilbert Paolini, Dept. of Spanish and Portuguese, Tulane Univ., New Orleans, LA 70118.

Southeast Conference on Romance Languages and Literatures, 10-12 Feb. 1983, Rollins Coll. Address Fidel Lopez-Criado, Rollins Coll., Winter Park, FL 32789.

Midwest Regional Conference on English in the TwoYear College, 17-19 Feb. 1983, Overland Park, KS. Address Judith C. Hanneken, Dept. of English, Community and Technical Coll. of the Univ. of Toledo, Toledo, OH 43606.

Applied Language Study: New Objectives, New Methods, 18-19 Feb. 1983, Oklahoma State Univ. Address John Joseph, Dept. of Foreign Langs., Oklahoma State Univ., Stillwater 74078.

Shakespeare Symposium Commemorating the Fiftieth Anniversary of the Horace Howard Furness Library, 18 Feb. 1983, Philadelphia. Address Georgianna Ziegler, Furness Collection, Van Pelt Library/CH, Univ. of Pennsylvania, Philadelphia 19104.

Baroque Festival, 23-27 Feb. 1983, St. Louis. Address William Matheson, Dept. of Comparative Lit., Campus Box 1107, Washington Univ., St. Louis, MO 63130.

Rage and Order in Twentieth-Century Literature, 23-25 Feb. 1983, Univ. of Louisville. Address Kathryn A. Wixon, Dept. of Classical and Modern Langs., Univ. of Louisville, Louisville, KY 40292.

Southern Comparative Literature Association, 24-26 Feb. 1983, Lexington, VA. Address Murray Vines, Dept. of Modern Langs., Virginia Military Inst., Lexington 24450, or Westbrook Barritt, Dept. of Romance Langs., Washington and Lee Univ., Lexington, VA 24450 .

Tennessee Philological Association, 24-26 Feb. 1983, Univ. of Tennessee. Address Styron Harris, Dept., of English, Box 20140A, East Tennessee State Univ., Johnson City 37614.

Center for Medieval and Renaissance Studies: The Rediscovery of Rome in the Late Middle Ages and Renaissance, 25-26 Feb. 1983, Ohio State Univ. Address Joseph H. Lynch, 322 Dulles Hall, Ohio State Univ., 230 W. 17th Ave., Columbus 43210.

Sonneck Society, 25-27 Feb. 1983, Philadelphia. Address Thomas Warner, Dept. of Music, Bucknell Univ., Lewisburg, PA 17837.

The Medieval Court in Europe: Humanities and Fine Arts Symposium, 2-5 March 1983, Houston. Address Carl Lindahl, Dept. of English, Univ. of Houston, Houston, TX 77004.
Ohio Shakespeare Conference: Responses to Shakespeare-Scholarly, Critical, Artistic, 3-5 March 1983, Oberlin Coll. Address Robert B. Pierce, Dept. of English, Oberlin Coll., Oberlin, OH 44074.

The Fantastic in the Arts: Gustave Doré-Illustrator of Cervantes and Rabelais, 10-12 March 1983, Boca Raton. Address Raymond LePage, Dept. of Foreign Langs. and Lits., George Mason Univ., Fairfax, VA 22030.

South Central Society for Eighteenth-Century Studies, 17-19 March 1983, Arizona State Univ. Address O. M. Brack, Jr., Dept. of English, Arizona State Univ., Tempe 85287.

Southeastern American Society for Eighteenth-Century Studies, 17-19 March 1983, Birmingham. Address Clara Gandy, Dept. of History, Coker Coll., Hartsville, SC 29550.

Tillie Olsen Symposium, 21-26 March 1983, Davenport. Address Lois Jecklin, Visiting Artists, Inc., 2717 Nichols Lane, Davenport, IA 52803.

American Comparative Literature Association, 24-26 March 1983, Univ. of California, Santa Barbara. Address Howard Clarke, Comparative Lit. Program, Univ. of California, Santa Barbara 93106.

French Literature Conference: The French NovelTheory and Practice, 24-26 March 1983, Univ. of South Carolina. Address Buford Norman, Dept. of Foreign Langs. and Lits., Univ. of South Carolina, Columbia 29208.

National Council of Teachers of English Conference on College Composition and Communication, 24-26 March 1983, Detroit. Address NCTE, 1111 Kenyon Road, Urbana, IL 61801.

Philological Association of the Carolinas, 24-26 March 1983, Charleston. Address William Naufftus, Dept. of English and Drama, Winthrop Coll., Rock Hill, SC 29733.

Purdue Conference on Film, 24-26 March 1983, Purdue Univ. Address Thomas P. Adler or Marshall Deutelbaum, Dept. of English, Purdue Univ., West Lafayette, IN 47907 .

Renaissance Society of America-South Central Renaissance Conference, 24-26 March 1983, Memphis. Address Louis Charles Stagg, Dept. of English, Memphis State Univ., Memphis, TN 38152.

Symposium on Pre-Pléiade Poetry, 24-25 March 1983, Univ, of New Orleans. Address Jerry Nash, Dept. of Foreign Langs., Univ. of New Orleans, New Orleans, LA 70148.

Pacific Northwest Renaissance Conference, 25-26 March 1983, Univ. of Alberta. Address Jean MacIntyre, Dept. of English, Univ. of Alberta, Edmonton, Alta., Canada T6G 2E5.

Southeastern Renaissance Conference, 25-26 March 1983, Univ. of Virginia. Address Henry E. Jacobs, 


\section{Oxford}

\section{The Will To Believe}

Novelists of the Nineteen-Thirties

RICHARD JOHNSTONE, Senior Lecturer in English, Hertfordshire College of Further

Education. The nineteen-thirties had a distinct literary character, dominated by writers who had in common not only their ages, but their backgrounds and education as well. This study of six novelists working during this period-Graham Greene, Evelyn Waugh, Christopher Isherwood, George Orwell, Edward Upward, and Rex Warner-reveals their powerful need for "something to believe in" in the wake of the order, continuity, and purpose lost from their lives as a result of the first world war.

1982160 pp. $\$ 29.50$

\section{The Complete Poetical Works of Thomas Hardy}

Volume I: Wessex Poems, Poems of the Past and the Present, Time's Laughingstocks Edited by SAMUEL HYNES, Professor of English, Princeton University. This complete, definitive edition of Hardy's poems incorporates revisions he made in print, in manuscripts, and in holograph corrections he made to his own copies of books. The editor's examination of public and private book collections, manuscripts, and letters in England, France, and the United Statesmany never before made available to scholars-allows him to describe the complex history of Hardy's poems and to explain why a correct text never appeared during Hardy's lifetime. (Oxford English Texts)

November 1982468 pp.; illus. $\$ 39.50$

\section{The Collected Letters of Thomas Hardy}

\section{Volume Three: 1902-1908}

Edited $b y$ RICHARD LITTLE PURDY and MICHAEL MILLGATE, Professor of English, University of Toronto. Scrupulously annotated and extensively cross-referenced, the text includes more than six hundred letters supplemented by a chronology covering the whole of Hardy's career and an index to the letter's recipients. From reviews of Volume One: "A thoroughly painstaking and professional achievement."-Choice. "The necessity of this volume for all Hardy collections cannot be overemphasized."-Library Journal.

1982320 pp.; 8 illus. $\$ 45.00$

\section{Tess of the d'Urbervilles}

THOMAS HARDY; edited by JULIET GRINDLE and SIMON GATRELL, Lecturer in English, New University of Ulster. This edition of Tess of the d'Urbervilles presents the novel exactly as Hardy wrote it, while also giving a detailed account of its writing and revision in the introduction. Although the Wessex Edition of 1912 is the version considered to have the greatest authority, the editors of this critical edition have collated every variety of the text from its manuscript to editions published after Hardy's death.

November $1982 \quad 600$ pp.; map $\$ 95.00$

\section{William Wordsworth}

\section{The Borders of Vision}

JONATHAN WORDSWORTH, Fellow in English, St. Catherine's College, University of Oxford. Wordsworth's sense of man as firmly based in the actual world, yet reaching out, aspiring beyond the limits of normal human experience, is the starting point of this new book. Adopting a broadly chronological approach, the author places famous passages of Wordsworth's poems in their original context and offers a fresh view of the poet's creative process and his strange imaginative vision.

1982464 pp. $\$ 34.95$

\section{The Rapes of Lucretia}

\section{A Myth and Its Transformations}

IAN DONALDSON, Director of the Humanities Research Centre of the Australian National University, Canberra. One of the most familiar of all stories from the ancient world, the rape of Lucretia was, to the Romans, a story of great political importance. This challenging new book sees the story as a myth and examines its origins and changing fortunes, looking at some of the ways in which it has been interpreted, criticized, elaborated, and transformed. 1982208 pp.; 20 illus. $\$ 27.50$ 
Dept. of English, P.O. Box AL, Univ. of Alabama, University 35486.

Friedrich Nietzsche and the Psychology of Resentment, 26-28 March 1983, Univ. of California, Santa Barbara. Address Ursula Mahlendorf and Laurence Rickels, Dept. of Germanic and Slavic Langs. and Lits., Univ. of California, Santa Barbara 93106.

Symposium on Comparative Literature and International Studies, 26-27 March 1983, Monterey. Address Elizabeth Welt Trahan, Monterey Inst. of International Studies, 425 Van Buren St., Monterey, CA 93940.

Conference on Humorous Metaphor, 31 March-2 April 1983, Phoenix. Address Don L. F. Nilsen, Dept. of English, Arizona State Univ., Tempe 85287.

Association for Literary and Linguistic Computing, 6-8 April 1983, San Francisco. Address James Joyce, ITS, Suite 1036, 2000 Center St., Berkeley, CA 94704.

Connections: A Baroque Festival Year, 7-9 April 1983, Calvin Coll. Address Chris Stoffel Overvoorde, Art Dept., Calvin Coll., Grand Rapids, MI 49506.

Foreign Languages for Business, 7-9 April 1983, Eastern Michigan Univ. Address Geoffrey M. Voght, Dept. of Foreign Langs. and Bilingual Studies, Eastern Michigan Univ., Ypsilanti 48197.

Georgia Colloquium '83: Irony in Modern Literature, 7-9 April 1983, Univ. of Georgia. Address A. G. Steer, Dept. of Germanic and Slavic Langs., Univ. of Georgia, Athens 30602.

Images and Identities: The Puerto Rican in Literature, 7-9 April 1983, Rutgers Univ. Address Asela Rodríguez de Laguna, Dept. of Foreign Langs., Conklin Hall, Rutgers Univ., Newark, NJ 07102.

North American Society for Seventeenth-Century French Literature: Voyages-Récits et imaginaires (textes et représentations figurées), 7-9 April 1983, Montreal. Address Bernard Beugnot, Département d'études françaises, Université de Montréal, CP 6128 Succ. A, Montréal, Qué., Canada H3C 3J7.

Shakespeare Association of America, 7-9 April 1983, Ashland, OR. Address Ann Jennalie Cook, 6328 Vanderbilt Station B, Nashville, TN 37235.

Southeastern American Studies Association, 7-9 April 1983, Coll. of Charleston. Address Norman Olsen, Jr., Dept. of English, Coll. of Charleston, Charleston, SC 29401.

Winthrop Symposium on Major Modern Writers: William Butler Yeats as Poet, Playwright, Folklorist, and Critic, 7-9 April 1983, Winthrop Coll. Address Jack W. Weaver, Dept. of English and Drama, Winthrop Coll., Rock Hill, SC 29733.

Colloquium on Literature: Poetry and the Arts, 8-9 April 1983, Illinois Wesleyan Univ. Address Salvador J. Fajardo and James McGowan, Colloquium on Literature, Illinois Wesleyan Univ., Bloomington 61701.
Rocky Mountain Medieval and Renaissance Association, 8-9 April 1983, Brigham Young Univ. Address Madison U. Sowell, Dept. of French and Italian, Brigham Young Univ., Provo, UT 84602.

Middle Atlantic Folklife Association: Folklore-The State of the Field, 9 April 1983, Salisbury State Coll. Address Simon J. Bronner, Folklore and American Studies, Pennsylvania State Univ., Capitol Campus, Middletown 17057.

Conference on Christianity and Literature (Far Westem Region), 14-15 April 1983, Loma Linda Univ. Address Robert P. Dunn, Dept. of English, Loma Linda Univ., Riverside, CA 92515.

Aging and the Imagination: Perspectives from Literature, Psychology, and Anthropology, 20-22 April 1983, Univ. of Wisconsin, Milwaukee. Address Kathleen Woodward, Center for Twentieth Century Studies, Univ. of Wisconsin, PO Box 413, Milwaukee 53201.

Northeast Victorian Studies Association: "Losers, Weepers"-Failure and Loss in the Victorian World, 22-24 April 1983, Boston Coll. Address Herbert Sussman, Northeastern Univ., Boston, MA 02115.

Society for Rousseau Studies, 22-24 April 1983, St. Olaf Coll. Address Mary Cisar, Dept. of Romance Langs., St. Olaf Coll., Northfield, MN 55057.

Société des Professeurs Français en Amérique: Les Grands Mouvances-De Québec à Haiti, 23 April 1983, New York. Address Société des Professeurs Français en Amérique, 22 E. 60th St., New York, NY 10022.

Popular Culture Association and American Culture Association, 24-27 April 1983, Wichita, KS. Address American Culture Assn., Bowling Green State Univ., Bowling Green, OH 43403.

Midwest Victorian Studies Association: Victorian Health and Victorian Disease, 29-30 April 1983, Chicago. Address Frederick Kirchhoff, Dept. of English and Ling., Indiana Univ.-Purdue Univ., Fort Wayne 46805.

West European Studies Symposium, 1-4 May 1983, Minneapolis. Address Martha Brogan, Library Coordinator, 180 Wilson Library, Univ. of Minnesota, Minneapolis 55455.

Sde Boqer Conference: Convention and Signification, 10-13 May 1983, Ben Gurion Univ., Israel. Address Noam Flinker, Dept. of Foreign Lits. and Ling., P.O. Box 653, Beersheva, Israel 84120 .

Pacific Northwest Council on Foreign Languages-Confederation of Oregon Foreign Language Teachers, 12-14 May 1983, Eugene. Address Ray Verzasconi, Dept. of Foreign Langs. and Lits., Oregon State Univ., Corvallis 97331.

Children's Literature Association, 14-16 May 1983, Edmonton, Canada. Address Roderick McGillis, Dept. of English, Univ. of Calgary, Calgary, Alta., Canada T2N $1 \mathrm{~N} 4$. 


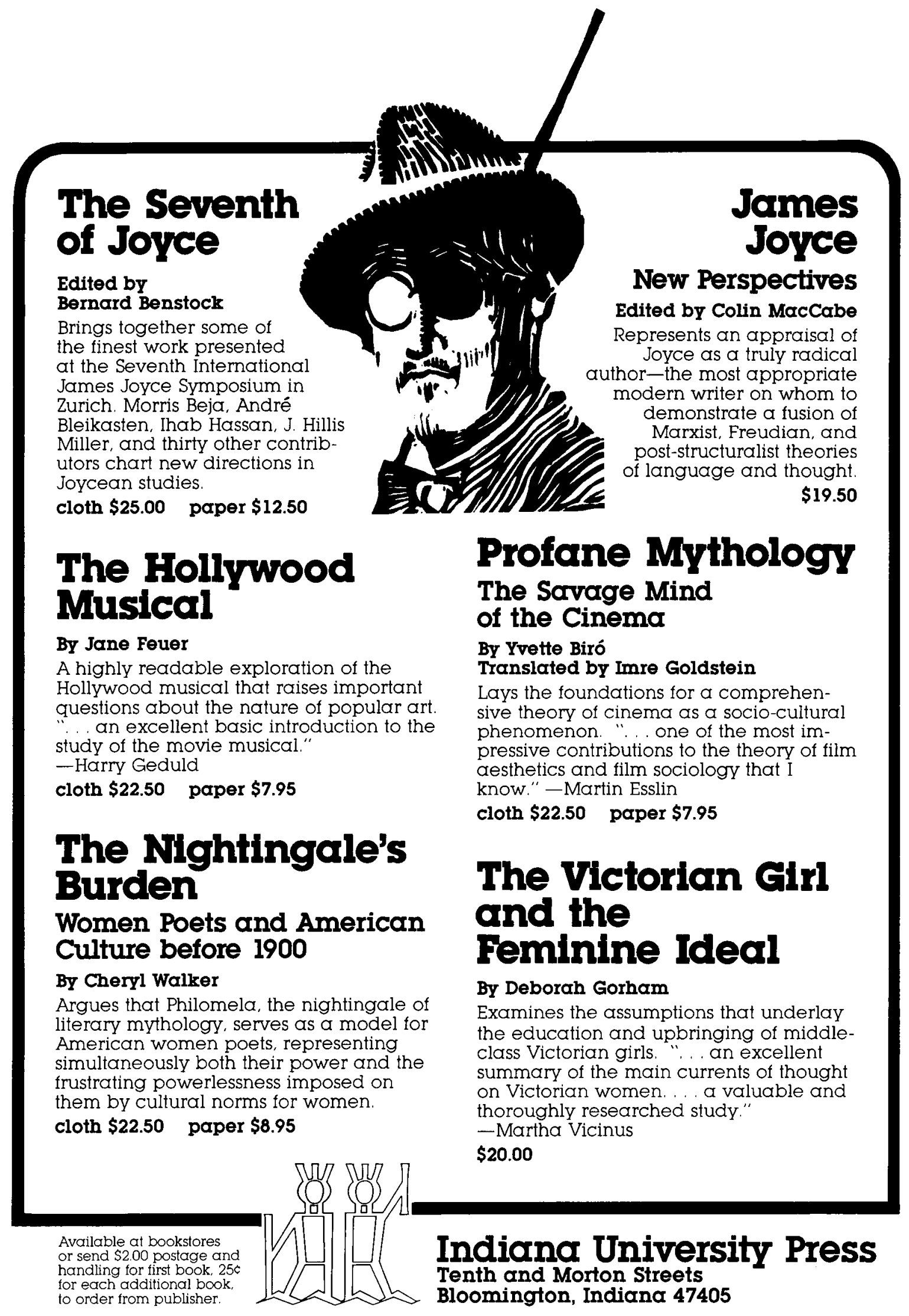


French American Studies Association: Aspects of Translation, 28-29 May 1983, Paris. Address M. Gresset, Association Française d'Etudes Américaines, 10, rue Charles v, Paris 75004, France.

The World as Mirror: Narcissism in Literature and the Fine Arts, 4-6 June 1983, Miami Univ. Address Donald W. Fritz, Dept. of English, Miami Univ., Oxford, OH 45056.

International Conference on Computers and the Humanities, 6-8 June 1983, Raleigh. Address Sarah K. Burton, Dept. of English, North Carolina State Univ., Raleigh 27607.

Dictionary Society of North America, 9-11 June 1983, Newark, DE. Address Roger J. Steiner, Dept. of Langs. and Lit., Univ. of Delaware, Newark 19711.

Blaise Cendrars International Society Colloquium: Blaise Cendrars and the English-Speaking World, 17-19 June 1983, Lonsdale Coll. Address Susan Taylor Horrex, Dept. of French Studies, Lonsdale Coll., Bailrigg, Lancaster, England LA1 4YN.

Sonneck Society, 2-5 July 1983, Univ. of Keele. Address Peter Dickinson, Dept. of Music, Univ. of Keele, Keele, Staffordshire, England ST5 5BG.

International Congress on the Enlightenment, 24-31 July 1983, Brussels. Address Hervé Hasquin, Group d'Etude du XVIIIe Siècle, Université Libre de Bruxelles, CP/142, av. Paul Héger 6, 1050 Brussels, Belgium.

International Courtly Literature Society, 8-13 Aug. 1983, Univ. of Toronto. Address Robert Taylor, Dept. of French, Victoria Coll., Toronto, Ont., Canada M5S $1 \mathrm{~K} 7$.

International Milton Symposium: Milton-Biography, Education, and Writing, 8-10 Aug. 1983, Cambridge, England. Address Ronald G. Shafer, Dept. of English, Indiana Univ. of Pennsylvania, Indiana, PA 15705.

American Association of Teachers of Spanish and Portuguese, 14-15 Aug. 1983, Boston. Address Richard B. Klein, AATSP, Holy Cross Coll., Worcester, MA 01610.

World Congress of Philosophy, 21-27 Aug. 1983, Montreal. Address Secretariat du XVIIe Congrès mondial de philosophie, Université de Montréal, C.P. 6128, Succursale A, Montréal, Qué., Canada H3C $3 J 7$.

Mikhail Bakhtin: His Circle and His Influence, 29 Sept.1 Oct. 1983, Queen's Univ. Address Clive Thomson, Dept. of French, Queen's Univ., Kingston, Canada K7L 3 N6.

McMaster Colloquium on German Literature: The Romantic Tradition-German Literature and Music in the Nineteenth Century, 13-15 Oct. 1983, McMaster Univ. Address Hans Schulte, Dept. of German, McMaster Univ., Hamilton, Ont., Canada L8S 4M2.
Romanticism in the Old World and the New: Stendhal, Zhukovskii, and Washington Irving, 13-16 Oct. 1983, Hofstra Univ. Address Natalie Datlof and Alexej Ugrinsky, Univ. Center for Cultural and Intercultural Studies, Hofstra Univ., Hempstead, NY 11550.

Committee for the Advancement of Early Studies Interdisciplinary Conference, 14-15 Oct. 1983, Ball State Univ. Address Bruce W. Hozeski, Dept. of English, Ball State Univ., Muncie, IN 47306.

American Studies Association, 3-6 Nov. 1983, Philadelphia. Address Executive Director, American Studies Assn., 307 College Hall/CO, Univ. of Pennsylvania, Philadelphia 19104.

Conference on Popular Culture in Latin America, 8-10 Nov. 1983, Las Cruces, NM. Address Harold Hinds, Div. of Social Sciences, Univ. of Minnesota, Morris 56267.

Espectador Universal: International José Ortega y Gasset Conference, 10-12 Nov. 1983, Hofstra Univ. Address Natalie Datlof and Alexej Ugrinsky, Univ. Center for Cultural and Intercultural Studies, Hofstra Univ., Hempstead, NY 11550.

The Multiethnic City: Conflict or Synthesis, 12-13 Nov. 1983, Pace Univ. Address Dorothy von Huene, Dept. of English, Pace Univ., New York, NY 10038.

National Council of Teachers of English, 18-26 Nov. 1983, Denver. Address NCTE, 1111 Kenyon Road, Urbana, IL 61801.

Semiotic Society of America, 26-30 Dec. 1983, San Francisco. Address Margot D. Lenhart, Semiotic Society of America, P.O. Box 10, Bloomington, IN 47402.

National Council of Teachers of English Conference on College Composition and Communication, 29-31 March 1984, New York. Address NCTE, 1111 Kenyon Road, Urbana, IL 61801.

Colloque Interdisciplinaire sur Jean Bodin, 25-26 May 1984, Université d'Angers. Address Georges Cesbron, Université d'Angers, Haute Perche, St. Melaine sur Aubance, 49320 Brissac Quince, France.

New Chaucer Society, 6-11 Aug. 1984, Univ. of York, England. Address John H. Fisher, Dept. of English, Univ. of Tennessee, Knoxville 37996.

International Arthurian Congress, 12-20 Aug. 1984, Rennes, France. Address Norris J. Lacy, Dept. of French and Italian, Univ. of Kansas, Lawrence 66045.

FILLM Congress, 21-27 Aug. 1984, Budapest. Address Secretariat, Országház u. 30 I. 48, H-1014 Budapest, Hungary.

National Council of Teachers of English, 16-21 Nov. 1984, Detroit. Address NCTE, 1111 Kenyon Road, Urbana, IL 61801. 


\section{A Poetics of Composition}

The Structure of the Artistic Text and Typology of a Compositional Form

\section{BORIS USPENSKY}

Translated by Valentina Zavarin and Susan Wittig

"Primarily intended as a contribution to the ongoing discussion of fictional point-of-view. . [this translation] makes available to us an important contribution to literary theory which all students of narrative will be glad to have."

$\$ 7.95$

- Comparative Literature

\section{Archery at the Dark of the Moon}

Poetic Problems in Homer's Odyssey

NORMAN AUSTIN

"I bless this volume for compelling me to think harder and to think differently about familiar passages on which after many years my views had crystallized. .. . Here is a book by a man who loves Homer, who thinks hard about Homer's magic, and who convinces one reader that he thoroughly enjoys sharing his thought with others." -Classical Outlook

$\$ 7.95$

\section{The Satires of Horace}

\section{NIALL RUDD}

"This happy blend of historical scholarship and literary criticism is aimed at a wide audience. It should afford profit and pleasure to students of the classical background to English literature as well as to students of Latin and to professional classical scholars." - Michael Coffey, The Classical Review

$\$ 9.95$

\section{Structure and History in Greek Mythology and Ritual}

\section{WALTER BURKERT}

"Burkert offers a rare combination of exact scholarship with imagination and even humor... he writes well and succinctly.

. [A] brilliant book." - Times Literary Supplement "The breadth alone of Burkert's learning renders this book indispensable."-Classical Outlook "The fare offered is tantalizingly rich and this is a splendid book."-Greece and Rome Sather Classical Lectures, 47.

$\$ 7.95$

\section{Literary Architecture}

Essays Toward a Tradition-

Walter Pater, Gerard Manley Hopkins, Marcel Proust, Henry James

ELLEN EVE FRANK

"This is a complex and important book... . a challenging and sophisticated contribution to critical studies of the sister arts. It originates from a thoroughly considered grasp of the imaginative possibilities of the analogy between architecture and literature, and it boldly brings an innovative critical method to bear." - Modern Language Quarterly $\$ 8.95$

\section{AT BOOKSTORES}

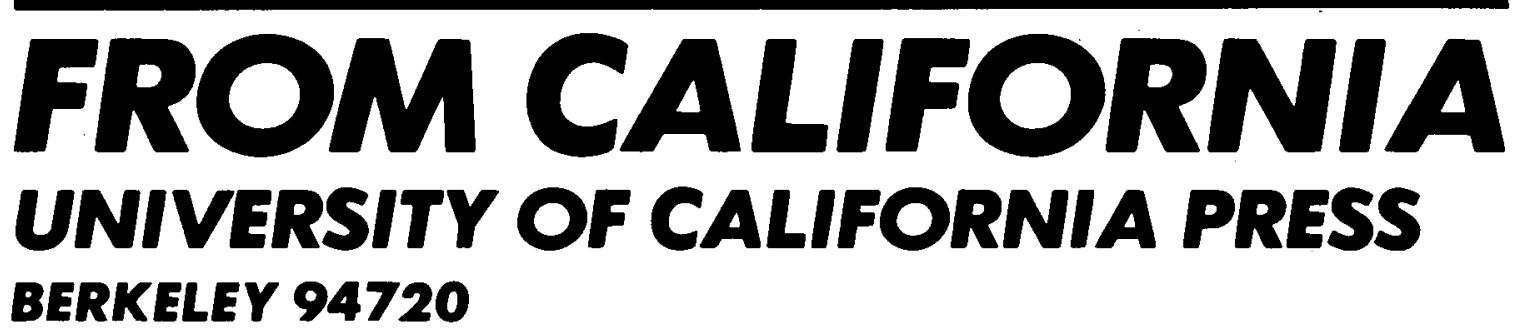

